\title{
Breastfeeding and complementary feeding in premature infants treated by a secondary reference service: a cohort study
}

\author{
Emanuelle Emília Ferreira Parreiras ${ }^{1}(\mathbb{0})$, Luciana Moreira Lima ${ }^{1}(\mathbb{D}$, \\ Tatiane Cristina Serafim ${ }^{1}\left({ }^{(0)}\right.$, Kelvin Oliveira Rocha' ${ }^{(0)}$, Felipe Oliveira Martins ${ }^{1}(\mathbb{D}$, \\ Brunnella Alcantara Chagas de Freitas'
}

'Universidade Federal de Viçosa, Viçosa, MG, Brasil

\begin{abstract}
Premature infants are vulnerable in the course of feeding practices, with lower rates of breastfeeding and inadequate feeding. To analyze breastfeeding rates, use of cow's milk and dietary inadequacies of premature infants in the second semester of Corrected Gestational Age (CGA), comparing them in two moments. This is a non-concurrent cohort with documentary analysis of medical records of 118 premature infants monitored at a secondary referral health service. Sociodemographic and perinatal data were analyzed in relation to the type of breastfeeding, feeding error and use of cow's milk in two moments: 6 months and 12 months of CGA. A reduction in breastfeeding rates was observed by the second semester of CGA (48.3\% vs. 36.4\%). The prevalence of dietary inadequacies was significant and showed no differences between the two periods ( 26.3 vs. $27.1 \%$ ), but the rates of use of cow's milk increased in the second moment (11\% vs. $26.3 \%$ ). Birth weight less than $2000 \mathrm{~g}$ was associated with a 4.2 times greater chance of artificial feeding in the first year of CGA. Low rates of breastfeeding, use of cow's milk and inadequate complementary feeding are expressive in premature infants whose families have low education and low income.
\end{abstract}

Keywords: Premature; Breastfeeding; Complementary Food; Weaning; Infant feeding; Cow milk; Followup; Cohort Studies 


\section{INTRODUCTION}

The World Health Organization recommends exclusive breastfeeding until the age of six months and its continuation together with complementary feeding for up to two years or more. The practice of breastfeeding brings great benefits to the infant in the short and long term, such as protection against infectious diseases, especially diarrhea and pneumonia, malnutrition and allergic processes, in addition to being associated with lower risks of developing type 2 diabetes and obesity (WHO, 2003; WHO, 2011; SANTOS et. al., 2019).

The incentive and support for breastfeeding should start during the prenatal period, and occur in the delivery room, in the joint accommodation and after hospital discharge, as well as in high-risk units that care for the newborn (SOCIEDADE BRASILEIRA DE PEDIATRIA, 2018). Breastfeeding practices have increased in Brazil, but the duration often still does not reach the recommendation. Research shows that two out of three children under the age of six months have already received some type of food in addition to breast milk, especially cow's milk, cow's milk plus some flour, juice, tea and sugar (MARINHO et. al., 2016; BRASIL, 2018).

The complementary feeding period for infants is defined as the gradual progression of the introduction of solid, semi-solid or liquid foods, in addition to breast milk. During this period, the introduction of food must be adequate and timely, since it will satisfy their nutritional needs, prevent diseases, assist in the psychological, motor and cognitive domains, as well as define the child's food preferences throughout life (MARINHO et. al., 2016; DAGNE et. al., 2016).

When the infant is unable to receive exclusive breastfeeding, the introduction of infant formulas is indicated, and the use of cow's milk until 12 months of age is contraindicated due to its allergenic potential, in addition to the large amount of proteins and low amount in iron, an important micronutrient for 
infants at this point in life (SOCIEDADE BRASILEIRA DE PEDIATRIA, 2018; SALDAN et. al., 2017).

In addition, children have been consuming little variety of fresh and minimally processed foods since the early years are being exposed to industrialized foods with low nutritional value very early. Early weaning and low quality and little varied food directly interfere with your nutritional and health status, impacting your adult life (SANTOS et. al., 2019; SOCIEDADE BRASILEIRA DE PEDIATRIA, 2018; MARINHO et. al., 2016; BRASIL, 2018; LAURA; ESTEVES; AZEVEDO, 2009).

Adequate breastfeeding practices and the introduction of complementary feeding are essential in the health of infants born at term and especially in preterm infants, as this group has a higher risk of postnatal growth restriction compared to full-term children, in addition to having high demand of nutrients due to the immaturity of their organs (BARACHETTI; BARBARINI, 2047; GRUPTA et. al., 2017; KOLETZKO; POINDEXTER; UAUY, 2014). Beyond biological risk inherent in premature birth, the socioeconomic conditions of the family must also be considered, given that low family income and maternal education influence early weaning and inadequate complementary feeding (GRUPTA et. al., 2017). Thus, premature infants, especially those born with very low weight, are at greater risk of morbidity and mortality, mainly of disorders related to growth, development and nutritional deficiencies. Knowing the superiority of breast milk as a primary food, breastfeeding should be started while in the progressive care unit and before hospital discharge, seeking to promote exclusive breastfeeding and encourage the mother-baby bond (KOLETZKO; POINDEXTER; UAUY, 2014; FREITAS; FURLAN, 2018).

Due to the various procedures during hospitalization to which premature babies are submitted, this group may present feeding difficulties, such as motor dysfunction, gastroesophageal reflux, choking, vomiting and aspiration, difficulty in consistency transition in addition to low weight gain (KOLETZKO; POINDEXTER; UAUY, 2014; PAGLIARO et. al., 2016). 
Despite the recognition in the scientific literature that premature babies are at increased risk of deviation from postnatal growth, including accelerated growth or failure to thrive, there are no evidence-based guidelines on the introduction of complementary feeding in premature infants (BALDASSARRE et. al., 2018; VISSERS et. al., 2016). The corrected gestational age (CGA) is used as a decision parameter to initiate the introduction of complementary feeding for the premature baby, since this feeding transition will depend on the infant's neurological maturity (PALMER; MAKRIDES, 2012).

In this context, the importance of the interdisciplinary team in monitoring preterm children is highlighted in order to provide adequate guidance to families at all levels of care (SOCIEDADE BRASILEIRA DE PEDIATRIA, 2012).

Based on the above, the present study aimed to analyze the rates of breastfeeding, use of cow's milk and dietary inadequacies of premature infants in the second semester of CGA, comparing them in two moments.

\section{METHODS}

This is a non-concurrent cohort study, with documentary analysis of medical records of premature infants followed up at a secondary health service in the municipality of Viçosa-Minas Gerais, between September 2010 and May 2018. This work is an excerpt from the research "Growth, development and morbidities of infants and preschoolers born preterm and / or with low birth weight", which consists of a prospective cohort, which implies semi-structured medical records and bank of data that is continuously updated. Thus, it was possible to obtain reliable data for the present study.

Sociodemographic and perinatal data were obtained to characterize the study population and data on the type of breastfeeding, feeding error and use of cow's milk were analyzed in two moments: 6 months (comprising premature infants between 4 and 6 months of (GA) and 12 months (between 10 and 12 
months of (GA). Premature infants who were not assessed at both times were excluded.

The hospital where all births in the municipality and health region occur has a Neonatal Intensive Care Unit since 2004 and a Human Milk Bank since 2005 became a reference for high-risk pregnancies in 2009 and a teaching hospital in 2013. Based on data obtained by the SUS Department of Informatics - DATASUS, of the 1516 births in 2016, $11.6 \%$ were premature.

The secondary referral health service, opened in September 2010, is the only referral service for premature infants in the municipality and health region, serving an approximate population of 227,000 people. An interdisciplinary team in the areas of pediatrics, nursing, nutrition, psychology, physiotherapy and social assistance performs the follow-up of premature infants in their first five years. At the time of hospital discharge, all preterm infants are referred to this service for follow-up and, until May 2018, there were 273 registered children. Both health units have an agreement with the Federal University of Viçosa for the training of resident doctors and undergraduate students in medicine and nursing.

In the follow-up of premature infants, consultations with the interdisciplinary team take place on a monthly basis in the first six months and every two months in the second semester. In these, the necessary nutritional interventions are carried out, with emphasis on the support and promotion of breastfeeding and the adequate introduction of complementary food.

Premature was defined as any newborn with a gestational age of less than 37 weeks. Chronological age was defined as postnatal age and CGA was characterized as the difference between gestational age at birth and average duration of a full-term pregnancy (40 weeks) (AMERICAN ACADEMY OF PEDIATRICS, 2017; INSTITUTE OF MEDICINE OF THE ACADEMIES, 2007).

The sociodemographic variables analyzed were: maternal and paternal age, maternal education (up to and beyond elementary school), maternal residence (study municipality / other municipality in the health region), maternal occupation 
(working outside the home or not), maternal marital status (single / divorced, stable / married). The perinatal variables evaluated were: type of delivery, sex, gestational age (weeks), birth weight (grams), birth small for gestational age (SGA), admission to the neonatal intensive care unit and discharge in breastfeeding.

The type of breastfeeding was categorized as breastfeeding (exclusive / supplemented) and artificial feeding. The feeding error (or inadequate feeding) was characterized by the introduction of cow's milk or by-products, inadequate dilution of the formula, inadequate composition of the main porridge, addition of flours to milk, use of juices or teas.

Through the Stat Calc Epi-Info 7.0 program and based on the rates of breastfeeding, use of cow's milk and dietary inadequacies, the assessed sample had $80 \%$ study power. The data were stored in a structured bank in the Excel program. The statistical analysis was performed using the IBM SPSS Software version 20. By the Shapiro-Wilk test, the normality of the quantitative variables was verified. Pearson's chi-square test was used to analyze the association between categorical variables. The comparative analysis of categorical data of preterm infants between 6-month and 12-month CGA was performed using the McNemar test. Multiple logistic regression by the Stepwise Backward method was applied to the explanatory variables that presented $p<0.20$ in the comparison tests and, subsequently, in the bivariate logistic regression, relating them to the variables of artificial feeding, food error and use of cow's milk in the first year of CGA. Values of $p<0.05$ were considered significant.

The study was approved by the Research Ethics Committee of the Federal University of Viçosa (CAAE: 19676613.5.0000.5153) and is in accordance with the Regulated Guidelines and Regulations for Research Involving Humans, in compliance with Resolution No. 580, of March 22, 2018, from the National Health Council of the Ministry of Health, Brasília, DF. 


\section{RESULTS}

The medical records of 273 premature infants were searched and, after applying the inclusion and exclusion criteria, the study population had 118 (43.2\%). The sociodemographic and perinatal characteristics of preterm infants are described in table 1, as well as the comparative analysis between those included and not included in the study, which did not show differences. Thus, there was no presence of selection bias due to differential losses. The population of premature infants was distributed as follows: $25.9 \%$ were born weighing less than 1,500g ( $\mathrm{n}=$ 30 ) and $74,1 \%$ weighing 1,500 g or more $(n=86) ; 23.7 \%$ were born with gestational age less than 32 weeks $(n=28)$ and $76.3 \%$ with 32 weeks or more $(n=90)$.

Table 1 - Comparative analysis between sociodemographic and perinatal characteristics of premature infants included and not included in the study. Viçosa-MG, 2010-2018

\begin{tabular}{|c|c|c|c|}
\hline Variables & Study population $(n=118)$ & Excluded $(n=155)$ & p-value \\
\hline GA (semanas) & $34,3(32,0-35,5)$ & $34,1(32,0-35,6)$ & $0,775^{\star}$ \\
\hline BW (g) & $1941,0(1488,05-2413,7)$ & $2048,0(1455-2472,0)$ & $0,880 *$ \\
\hline Maternal age & $28,0(24,0-33,0)$ & $27,0(21,0-32,0)$ & $0,180 *$ \\
\hline Father's age & $29,0(25,0-37,0)$ & $29,0(23,0-37,0)$ & $0,410 *$ \\
\hline Born SGA & $17(41,5)$ & $24(58,5)$ & $0,918^{* *}$ \\
\hline Cesarean delivery & $72(40,4)$ & $106(59,6)$ & $0,294 * *$ \\
\hline Male & $66(42,0)$ & $91(58,0)$ & 0,646 ** \\
\hline NICU admission & $83(40,3)$ & $123(59,7)$ & $0,092 * *$ \\
\hline Hospital discharge in BF & $95(32,3)$ & $118(44,8)$ & $0,400 * *$ \\
\hline Mother resident in another municipality & $53(44,2)$ & $67(55,8)$ & 0,781 ** \\
\hline Maternal schooling ( $\leq$ fundamental) & $38(43,7)$ & $49(56,3)$ & $0,890 * *$ \\
\hline Maternal occupation (works outside) & $55(47,4)$ & $61(52,6)$ & 0,511 ** \\
\hline Maternal marital status (single / divorced) & $29(11,2)$ & $32(12,4)$ & $0,746 * *$ \\
\hline
\end{tabular}

Source: Authors (2020)

In were: GA, gestational age; BW, birth weight; SGA, small for gestational age; NICU, neonatal intensive care unit; BF, breastfeeding (exclusive or supplemented). Values expressed in absolute and relative frequency (\%); median and interquartile range (P25-P75). * Mann-Whitney test. ** Pearson's Chi-square test. 
When comparing preterm infants at 6 months and 12 months of CGA (figures 1,2 and 3), a reduction in the prevalence of breastfeeding was observed (48.3\% vs. $36.4 \%, p=0.001)$ accompanied increased frequency of artificial feeding (51.7\% vs. $63.6 \%, p=0.001)$. The prevalence of food errors did not show differences between the two moments $(26.3 \%$ vs. $27.1 \%, p=1,000)$. However, when analyzing the rates of use of cow's milk, these increased at 12 months of CGA $(11.0 \%$ vs. $23.6 \%$, p $<0.001)$.

Figure 1 - Prevalence of breastfeeding (BF) and artificial feeding (AA) at 6 months and at 12 months of corrected gestational age. Premature infants, 2010-2018 $(n=118)$. * McNemar test

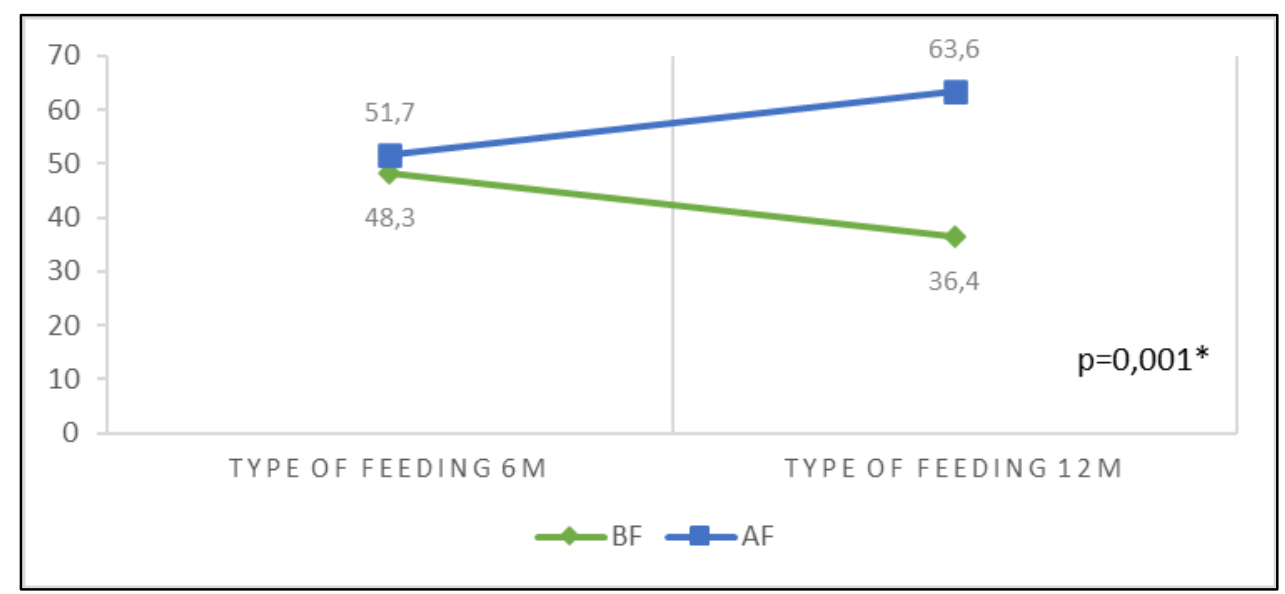

Source: Authors (2020)

Figure 2 - Prevalence of feeding errors at 6 months and 12 months of corrected gestational age. Premature infants, 2010-2018 $(n=118)$. * McNemar test

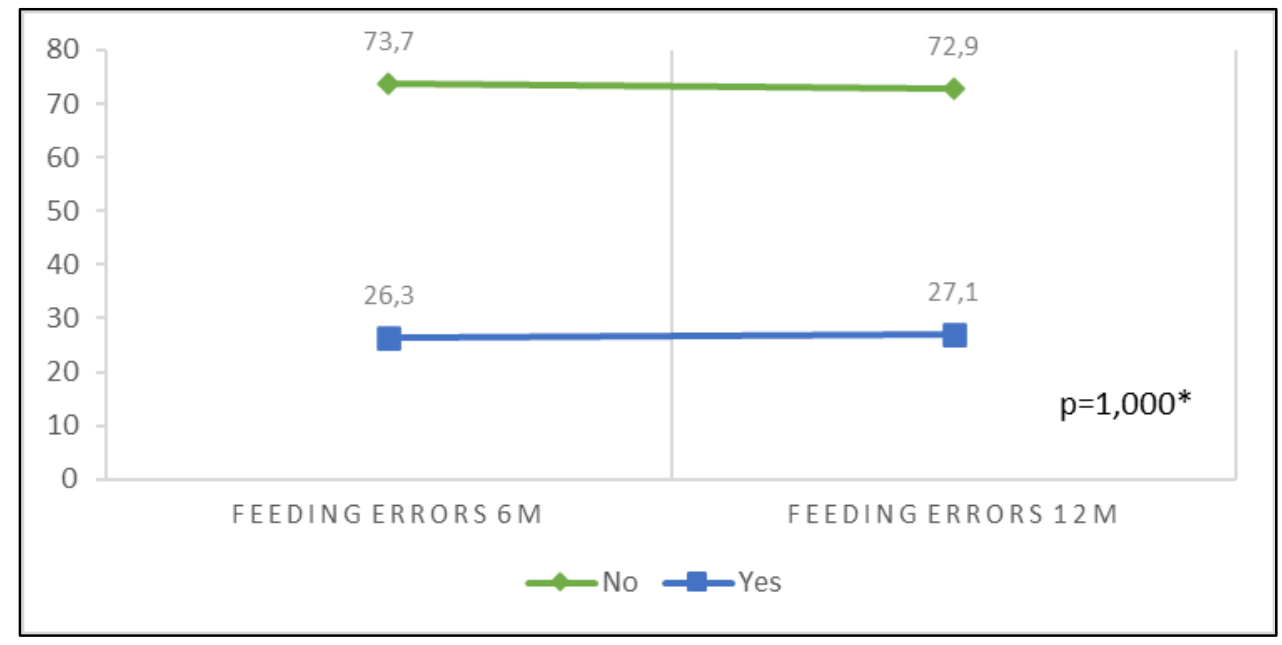

Source: Authors (2020)

Ci. e Nat., Santa Maria, v.43, Ed. Esp. UFV,e21, 2021 
Figure 3 - Prevalence of using cow's milk at 6 months and 12 months of corrected gestational age. Premature infants, 2010-2018 $(n=118)$. * McNemar test

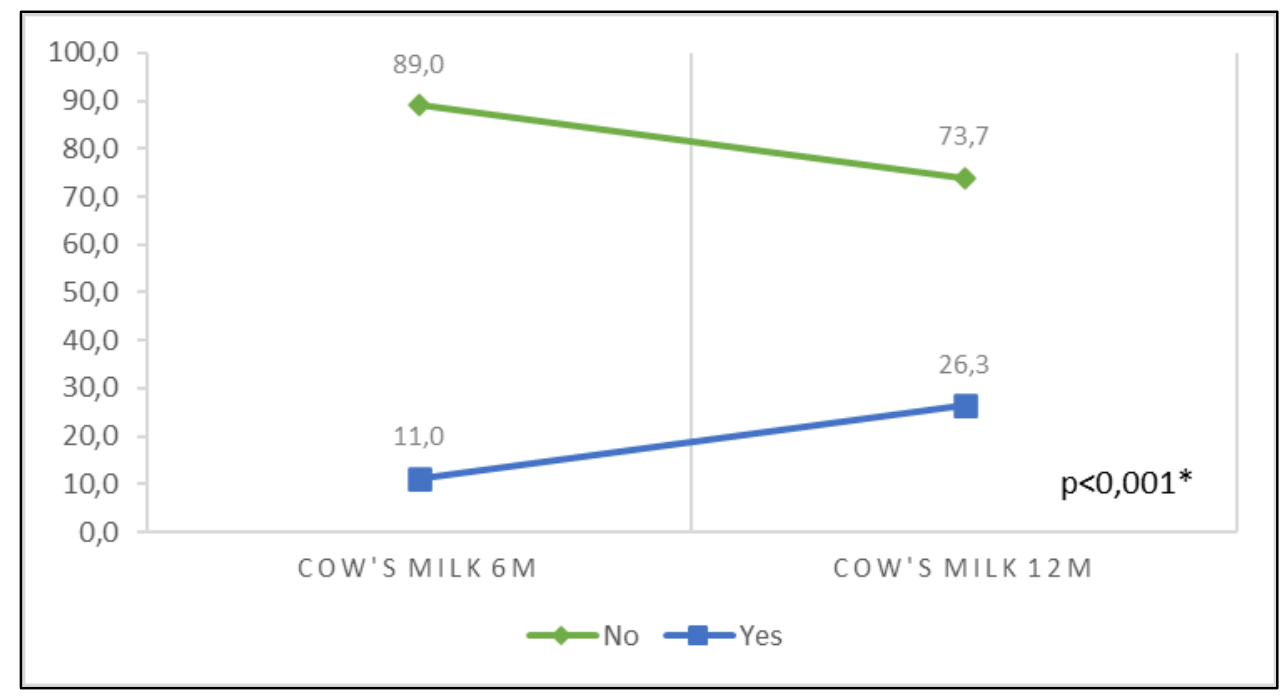

Source: Authors (2020)

The variables that, in the comparison tests, presented $p<0.20$ for the outcomes are artificial feeding, feeding error and use of cow's milk in the first year of CGA (Table 2). These were submitted to bivariate logistic regression. For the outcomes food error and use of cow's milk, the associations were not confirmed. The variables gestational age, birth weight and previous hospitalization in the NICU constituted the multivariate model for the outcome of artificial feeding in the first year. In the end, birth weight $<2000 \mathrm{~g}$ was associated with a greater chance of artificial feeding in the first year of CGA (OR 4.17; $95 \% \mathrm{Cl} 1.85-9.39 ; \mathrm{p}=0.001)$.

Table 2 - Sociodemographic and perinatal characteristics according to the prevalence of breastfeeding, feeding error and use of cow's milk in the first year of corrected gestational age. Premature, Viçosa-MG, 2010-2018

\begin{tabular}{|c|c|c|c|c|c|c|c|c|c|}
\hline & \multicolumn{3}{|c|}{ Artificial feeding } & \multicolumn{3}{|c|}{ Feeding error } & \multicolumn{3}{|c|}{ Cow milk } \\
\hline & Yes & No & p-value & Yes & No & p-value & Yes & No & p-value \\
\hline GA (weeks) & & & 0,003 & & & - & & & - \\
\hline$<34$ & $40(78,4)$ & $11(21,6)$ & & - & - & & - & - & \\
\hline$\geq 34$ & $35(52,2)$ & $32(47,8)$ & & - & - & & - & - & \\
\hline
\end{tabular}


10 | Breastfeeding and complementary feeding in premature infants treated by a secondary...

\begin{tabular}{|c|c|c|c|c|c|c|c|c|c|}
\hline \multicolumn{10}{|l|}{ Conclusion } \\
\hline & \multicolumn{3}{|c|}{ Artificial feeding } & \multicolumn{3}{|c|}{ Feeding error } & \multicolumn{3}{|c|}{ Cow milk } \\
\hline & Yes & No & p-value & Yes & No & p-value & Yes & No & p-value \\
\hline BW (grams) & & & 0,001 & & & - & & & - \\
\hline$<2000$ & $48(77,4)$ & $14(22,6)$ & & - & - & & - & - & \\
\hline$\geq 2000$ & $25(43,6)$ & $29(53,7)$ & & - & - & & - & - & \\
\hline NICU & & & 0,062 & & & - & & & - \\
\hline Yes & $57(38,7)$ & $26(31,3)$ & & - & - & & - & - & \\
\hline No & $16(50,0)$ & $16(50,0)$ & & - & - & & - & - & \\
\hline $\begin{array}{l}\text { Maternal } \\
\text { schooling }\end{array}$ & & & - & & & 0,075 & & & 0,120 \\
\hline $\begin{array}{l}\leq \\
\text { fundamental } \\
>\end{array}$ & - & - & & $20(52,6)$ & $18(47,4)$ & & $14(36,8)$ & $24(63,2)$ & \\
\hline fundamental & - & - & & $26(35,1)$ & $48(64,9)$ & & $17(23,0)$ & $57(77,0)$ & \\
\hline $\begin{array}{l}\text { Mother has } \\
\text { partner }\end{array}$ & & & - & & & 0,114 & & & 0,119 \\
\hline Yes & - & - & & $31(38,3)$ & $50(61,7)$ & & $21(25,9)$ & $60(74,1)$ & \\
\hline No & - & - & & $16(55,2)$ & $13(44,8)$ & & $12(41,4)$ & $17(58,6)$ & \\
\hline
\end{tabular}

Source: Authors (2020)

In were: GA, gestational age; BW, birth weight; NICU, neonatal intensive care unit. The table shows data showing $p<0.20$ by Pearson's Chi-square test. Bivariate logistic regression was performed for the three outcomes. Only for artificial feeding in the first year it was possible to build the multivariate model and, in the end, its association with birth weight <2000g persisted (OR 4.17; 95\% Cl 1.85-9.39; $\mathrm{p}=0.001$ ).

\section{DISCUSSION}

In the present study, a reduction in breastfeeding rates was observed in the course of the second semester of CGA of premature infants (48.3\% vs. $36.4 \%)$ and the birth weight below 2000g was associated with 4.2 times greater chance of artificial feeding in the first year of CGA. A study previously carried out with the population of our service identified a median duration of breastfeeding of only five months, whose interruption was associated with gestational age of less than 32 weeks and the fact that the premature infant was no longer exclusively breastfeeding in the first outpatient visit (DE FREITAS et. al., 2016).

Brazilian cohort reveals a reduction in exclusive breastfeeding rates between seven and 15 days after discharge of premature infants, with variations of $81.5 \%$ at 
discharge and $66.4 \%$ between seven and 15 days after. Its interruption was associated with the variables birth weight, double pregnancy and duration of ventilation (LUZ et. al., 2018). Thus, it is evident the need to implement actions that promote the early initiation and maintenance of exclusive breastfeeding for premature infants.

A prospective Italian study with late preterm infants shows low rates of breastfeeding, in addition to its early interruption in the first 90 days of life. At the time of discharge, exclusive breastfeeding rates were $16.8 \%$, reaching $40.3 \%$ and $31.1 \%$ at 15 days and 90 days, respectively. The respective rates of mixed breastfeeding at discharge, 15 days and 90 days were $75.8 \%, 47.8 \%$ and $21.0 \%$. At 90 days of life, $42.9 \%$ of premature infants were already on artificial feeding. It was observed that mothers with higher levels of education and previous experience of positive breastfeeding had a longer duration of breastfeeding, while the negative factors for breastfeeding were the feeling of reduced milk supply and having twins (CRIPPA, 2019).

In our study, the prevalence of food errors was significant and showed no differences between the two periods analyzed (26.3 vs. $27.1 \%$ ). However, when analyzing the rates of use of cow's milk, these increased in the second evaluation moment (11\% vs. $26.3 \%)$. An Italian cohort study with preterm infants identifies the early introduction of complementary foods, whose average postnatal age is $5.7 \pm$ 0.7 months and, when considering CGA, $4.6 \pm 0.7$ months. This same study also shows significant rates of early introduction of cow's milk (26\%), addition of salt (26\%) and industrialized fruit juice (32\%) (GIANNI et. al., 2018).

The use of unmodified cow's milk is inappropriate for feeding infants under the age of 12 months and is a major contributor to the high incidence of iron deficiency anemia in infants in Brazil (DURYEA, 2019). Among the inadequacies, the following stand out: low levels of essential fatty acids, quantity and quality of carbohydrates, high protein content and high sodium rates, contributing to the elevation of the renal solute load, low levels of vitamins C, D and E and low 
bioavailability of iron and zinc. Thus, the Brazilian Society of Pediatrics recommends that ultra-processed foods or with added salt, sugar and low nutritional quality should not be offered to children under two years of age, as, in addition to decreasing the infant's appetite and competing with foods of important importance nutritional value, are associated with the development of anemia, overweight and food allergies (SOCIEDADE BRASILEIRA DE PEDIATRIA, 2018).

For the introduction of complementary feeding for premature babies, it is necessary to assess their neurological maturity and, therefore, it is recommended to start complementary feeding at six months of CGA (PALMER; MAKRIDES, 2012; SOCIEDADE BRASILEIRA DE PEDIATRIA, 2012). In addition to the risk of restricting extrauterine growth to which preterm infants are exposed, inadequate behaviors regarding the introduction of complementary feeding can lead to the development of nutritional deficiencies and food allergies, increasing their morbidity and mortality. As future losses, growth retardation, school delay and the development of chronic non-communicable diseases stand out (GRUPTA et. al., 2017; BRASIL, 2013).

In this sense, identifying the best strategy for introducing complementary food in terms of growth, neurodevelopment and long-term metabolic results is essential. This can also alleviate the anxiety of parents who often receive conflicting advice from healthcare professionals. However, there is a lack of guidance in the literature and a lack of evidence-based strategies on the introduction of complementary feeding for premature infants (VISSERS et. al., 2016; ELFZZANI et. al., 2019). Thus, more research is needed to provide evidence-based guidelines for premature babies that investigate the relationships between dietary patterns, the timing of the introduction of solid foods and immediate and long-term health outcomes (BARACHETTI; VILLA; BARBARINI, 2017; GRUPTA et. al., 2017).

In our study, $43.7 \%$ of mothers had low education and $47.4 \%$ worked outside the home. Prospective cohort conducted in 2014 with the population of our service showed family income below two minimum wages in $46.6 \%$ of cases, in addition to 
low maternal and paternal education ( $44.8 \%$ and $55.2 \%$, respectively) (FREITAS et. al., 2016). An Australian study links women with low education or with low education relatives to a greater likelihood of not breastfeeding for at least six months (HOLOWKO et. al., 2016). According to a multicenter Indian study, low family income and maternal education influence early weaning and inadequate complementary feeding (GRUPTA et. al., 2017). Brazilian cohort conducted in our municipality, with infants in the first six months, identifies maternal work, low income and low birth weight as risk factors for the introduction of cow's milk in the sixth month and, in addition, relevant rates of introduction of other types of milk from the first month (CARVALHO et. al., 2017).

A Brazilian cohort in a low-income community reports a reduction in exclusive breastfeeding rates between the first and sixth months, ranging from $65 \%$ to $5 \%$, respectively. Low maternal education and low family income were risk factors for the early introduction of other milks (MACIEL et. al., 2018). Another Brazilian study with full-term infants shows the median duration of exclusive breastfeeding of 90 days. Powdered milk and soft drinks were used at four months by $39.1 \%$ and $2.1 \%$ of infants, respectively, and at 12 months, by 63.2 and $69.1 \%$. The shorter duration of breastfeeding was observed in women with technical jobs, unemployed and without a partner (LAURA; ESTEVES; AZEVEDO, 2009). In a study with children living in municipalities with high socioeconomic vulnerability in the southern region of Brazil, the introduction of non-recommended foods before the age of four months was observed in $47.8 \%$ of the cases, a fact that was associated with lower maternal education and lower family income (DALLAZEN et. al., 2018).

Brazilian authors point out that there are difficulties in establishing exclusive breastfeeding until hospital discharge and maintaining it at home, a possible indication of the failure of current practices and policies in this regard. They also emphasize that the guidelines of the "Child-Friendly Hospital" do not consider the particularities of the premature infant and the difficulties generated by the hospitalization process itself in a neonatal unit. Thus, it is essential to implement 
actions based on scientific evidence by the multiprofessional health team and its articulation with the Primary Care health team for the continuity of care at home, aiming at maintaining exclusive breastfeeding until six months of age (LUZ et. al., 2018).

Randomized clinical trial conducted in the South of Brazil reveals that the training of Primary Care health professionals based on the Brazilian Guide entitled "Ten steps to a healthy diet - Food guide for children under two years old" is effective in improving practices infant feeding among children from low-income families. The study made it possible to postpone the introduction of added sugar, tea, jam and cookies (BRASIL, 2013; FERREIRA et. al., 2019).

The frequent monitoring of health in the first year of life with trained professionals is essential to better guide mothers and caregivers on the introduction of appropriate complementary feeding. The acquisition of recommended dietary patterns implies changes in family behavior and requires planning of counseling strategies (GRUPTA et. al., 2017). However, it is noted that the implementation of public policies aimed at prevention and nutritional education actions as part of the routine activities of health services still occurs in an insufficient way to interfere in this reality and have an impact (DALLAZEN et. al., 2018).

A limitation of this study was the absence of the family income variable, since there is evidence in the literature of its association with the interruption of breastfeeding, dietary inadequacies and use of cow's milk in the first year of life. This fact was minimized by the evidence of the expressive rate of low family income and low paternal education in our population based on previous studies obtained in our service. We highlight the strengths of the cohort design, the reliability of the data obtained from the semi-structured medical records and the continuously updated database, and, in addition, the Follow-Up of premature infants stands out uninterruptedly in the reference health service, since the literature is scarce for cohort studies with preterm infants after hospital discharge. 


\section{CONCLUSION}

Based on the present study, we conclude that the low rates of breastfeeding, the use of cow's milk and inadequate complementary feeding are expressive in a population of premature infants whose families have low education and low income. Our findings indicate that the health monitoring of these premature infants at all levels of care is urgent, especially in the first year of life with professionals trained for better results regarding breastfeeding and complementary feeding. However, we observed that the literature is still scarce in relation to studies with the premature population from this perspective. Thus, there is still a long way to go to ensure breastfeeding and adequate complementary feeding for premature infants, with an emphasis on those with birth weight below $2000 \mathrm{~g}$ and whose families have low education and low family income.

We intend, based on our results, to support the development of educational strategies involving trained professionals and aimed at the families of this vulnerable public, in order to increase the rates and duration of breastfeeding and provide the introduction of healthy complementary food.

\section{REFERENCES}

AAP (AMERICAN ACADEMY OF PEDIATRICS) \& The American College of Obstetricians and Gynecologists. Guidelines for Perinatal Care [Internet]. Eighth. Elk Grove Village; 2017. Available from: http://reader.aappublications.org/guidelines-for-perinatal-care- 8th-edition/1

Baldassarre ME, Di Mauro A, Pedico A, Rizzo V, Capozza M, Meneghin F, et al. Weaning Time in Preterm Infants: An Audit of Italian Primary Care Paediatricians. Nutrients. 2018 May; 10(5).

Barachetti R, Villa E, Barbarini M. Weaning and complementary feeding in preterm infants: management, timing and health outcome. Pediatr Med Chir. 2017 Dec;39(4):181.

Brasil. Ministério da Saúde, Departamento de Atenção Básica, Coordenação-Geral de Alimentação e Nutricão. Guia alimentar para crianças menores de $\mathbf{2}$ anos. Ministério da Saúde. Brasília: Ministério da Saúde; 2018. 
Brasil. Ministério da Saúde. Dez passos para uma alimentação saudável: Guia alimentar para menores de dois anos - Um guia para o profissional da saúde na atenção básica. Brasília: MS. (Série A. Normas e Manuais Técnicos). 2nd ed. Vol. $2^{a}$ Edição, Guia alimentar para menores de dois anos. Brasília: Ministério da Saúde; 2013.

Carvalho CA de, Fonsêca PC de A, Nobre LN, Silva MA, Pessoa MC, Ribeiro AQ, et al. Fatores sociodemográficos, perinatais e comportamentais associados aos tipos de leite consumidos por crianças menores de seis meses: coorte de nascimento . Vol. 22, Ciência \& Saúde Coletiva. scielo ; 2017. p. 3699-710.

Crippa BL, Colombo L, Morniroli D, Consonni D, Bettinelli ME, Spreafico I, et al. Do a Few Weeks Matter? Late Preterm Infants and Breastfeeding Issues. Nutrients. 2019 Feb;11(2).

Dagne AH, Anteneh KT, Badi MB, Adhanu HH, Ahunie MA, Tebeje HD, et al. Appropriate complementary feeding practice and associated factors among mothers having children aged 6-24 months in Debre Tabor Hospital, North West Ethiopia, 2016. BMC Res Notes [Internet]. 2019;12(1):215. Available from: https://doi.org/10.1186/s13104-019-4259-3

Dallazen C, Silva SA da, Gonçalves VSS, Nilson EAF, Crispim SP, Lang RMF, et al. Introdução de alimentos não recomendados no primeiro ano de vida e fatores associados em crianças de baixo nível socioeconômico . Vol. 34, Cadernos de Saúde Pública. scielo ; 2018.

de Freitas BAC, Lima LM, Carlos CFLV, Priore SE, do Carmo Castro Franceschini S. Duration of breastfeeding in preterm infants followed at a secondary referral service. Rev Paul Pediatr (English Ed [Internet]. 2016 Jun;34(2):189-96. Available from: http://linkinghub.elsevier.com/retrieve/pii/S2359348216000233.

Duryea TK. Introducing solid foods and vitamin and mineral supplementation during infancy. UpToDate. 2019;march.

Elfzzani Z, Kwok TC, Ojha S, Dorling J. Education of family members to support weaning to solids and nutrition in infants born preterm. Cochrane database Syst Rev. 2019;2(2):CD012240.

Ferreira VR, Sangalli CN, Leffa PS, Rauber F, Vitolo MR. The impact of a primary health care intervention on infant feeding practices: a cluster randomised controlled trial in Brazil. J Hum Nutr Diet [Internet]. 2019 Feb 1;32(1):21-30. Available from: https://doi.org/10.1111/jhn.12595.

Freitas BAC, Furlan LR. Avaliação do lactente prematuro. In: SCC, Ribeiro SAV, Priore SE, Novaes JF, editor. Nutrição e Saúde da Criança. Rio de Janeiro: Ed Rubio; 2018. p. 633-42.

Freitas BAC de, Lima LM, Moreira MEL, Priore SE, Henriques BD, Carlos CFLV, et al. Micronutrient supplementation adherence and influence on the prevalences of anemia and iron, zinc and vitamin A deficiencies in preemies with a corrected age of six months. Clinics [Internet]. 2016 Aug 10;71(8):440-8. Available from: http://www.ncbi.nlm.nih.gov/pmc/articles/PMC4975790/. 
Gupta S, Agarwal R, Aggarwal KC, Chellani H, Duggal A, Arya S, et al. Complementary feeding at 4 versus 6 months of age for preterm infants born at less than 34 weeks of gestation: a randomised, open-label, multicentre trial. Lancet Glob Heal. 2017 May;5(5):e501-11.

Gianni ML, Bezze E, Colombo L, Rossetti C, Pesenti N, Roggero P, et al. Complementary Feeding Practices in a Cohort of Italian Late Preterm Infants. Nutrients. 2018 Dec;10(12).

Holowko N, Jones M, Koupil I, Tooth L, Mishra G. High education and increased parity are associated with breast-feeding initiation and duration among Australian women. Public Health Nutr. 2016 Oct;19(14):2551-61.

Institute of Medicine of the Academies. Preterm Birth: Causes, Consequences, and Prevention [Internet]. Washington, D.C.: The National Academies Press; 2007. Available from: https://www.nap.edu/catalog/11622/preterm-birth-causes-consequences-and-prevention.

Koletzko B, Poindexter B, Uauy R. Care of Preterm Infants: Scientific Basis and Practical Guidelines. Basel: Karger; 2014.

Laura Delbue Bernardi J, Esteves Jordão R, Azevedo Barros Filho A. Alimentação complementar de lactentes em uma cidade desenvolvida no contexto de um país em desenvolvimento. Vol. 26, Revista Panamericana De Salud Publica-pan American Journal of Public Health - REV PANAM SALUD PUBLICA. 2009.

Luz LS, Minamisava R, Scochi CGS, Salge AKM, Ribeiro LM, Castral TC. Predictive factors of the interruption of exclusive breastfeeding in premature infants: a prospective cohort . Vol. 71, Revista Brasileira de Enfermagem . scielo ; 2018. p. 2876-82.

Maciel B, Moraes ML, Soares AM, Cruz I, de Andrade M, Filho JQ, et al. Infant feeding practices and determinant variables for early complementary feeding in the first 8 months of life: results from the Brazilian MAL-ED cohort site. Public Health Nutr. 2018 Sep;21(13):2462-70.

Marinho LMF, Capelli J de CS, Rocha CMM da, Bouskela A, Carmo CN do, Freitas SEAP de, et al. Situação da alimentação complementar de crianças entre 6 e 24 meses assistidas na Rede de Atenção Básica de Saúde de Macaé, RJ, Brasil. Cien Saude Colet [Internet]. 2016 Mar [cited 2019 Apr 23];21(3):977-86. Available from: http://www.scielo.br/scielo.php?script=sci_arttext\&pid=S1413-

$81232016000300977 \&$ Ing=pt\&tlng=pt.

Pagliaro CL, Bühler KEB, Ibidi SM, Limongi SCO. Dietary transition difficulties in preterm infants: critical literature review. Vol. 92, Jornal de Pediatria. scielo ; 2016. p. 7-14.

Palmer DJ, Makrides M. Introducing solid foods to preterm infants in developed countries. Ann Nutr Metab. 2012;60 Suppl 2:31-8. 
Pan American Health Organization. Guiding Principles for Complementary Feeding of the Breastfed Child. Whashington, D.C.: Pan American Health Organization, World Health Organization; 2003.

Saldan PC, Venancio SI, Saldiva SRDM, Vieira DG, Mello DF de. CONSUMO DE LEITES EM MENORES DE UM ANO DE IDADE E VARIÁVEIS ASSOCIADAS AO CONSUMO DE LEITE NÃO MATERNO . Vol. 35, Revista Paulista de Pediatria. scielo ; 2017. p. 407-14.

Santos IS, Barros FC, Horta BL, Menezes AMB, Bassani D, Tovo-Rodrigues L, et al. Breastfeeding exclusivity and duration: trends and inequalities in four population-based birth cohorts in Pelotas, Brazil, 1982-2015. Int J Epidemiol [Internet]. 2019 Mar 18;48(Supplement_1):i72-9. Available from: https://doi.org/10.1093/ije/dyy159.

Sociedade Brasileira de Pediatria, Departamento Científico de Neonatologia. Seguimento ambulatorial do prematuro de risco. São Paulo: Sociedade Brasileira de Pediatria; 2012.

Sociedade Brasileira de Pediatria, Departamento Científico de Nutrologia. Manual de Alimentação: orientações para alimentação do lactente ao adolescente, na escola, na gestante, na prevenção de doenças e segurança alimentar. 4th ed. São Paulo: SBP; 2018.

Vissers KM, Feskens EJM, van Goudoever JB, Janse AJ. The timing of complementary feeding in preterm infants and the effect on overweight: study protocol for a systematic review. Syst Rev. 2016 Sep;5(1):149.

WHO. Statement: exclusive breastfeeding for six months best for babies everywhere. 2011.

\section{Authorship contributions}

\section{1 - Emanuelle Emília Ferreira Parreiras}

Universidade Federal de Viçosa, Viçosa, MG, Brasil. Departamento de Medicina e Enfermagem. Mestre em Ciências da Saúde.

https://orcid.org/0000-0003-3216-2955 - manuparreiras89@gmail.com

Contribuição: Conceptualização, análise formal, metodologia, escrita - rascunho original, escrita - revisão e edição.

\section{2 - Luciana Moreira Lima}

Universidade Federal de Viçosa, Viçosa, MG, Brasil. Departamento de Medicina e Enfermagem. Doutorado em Ciências Farmacêuticas.

https://orcid.org/0000-0001-5349-1577 - lucianamoreiralima@yahoo.com.br Contribuição: Metodologia, escrita - revisão e edição.

\section{3 - Tatiane Cristina Serafim}

Universidade Federal de Viçosa, Viçosa, MG, Brasil. Departamento de Medicina e Enfermagem. Mestre em Ciências da Saúde. 
https://orcid.org/0000-0003-1377-6214 - tatiane.serafim@ufv.br

Contribuição: Escrita- rascunho original.

\section{4 - Kelvin Oliveira Rocha}

Universidade Federal de Viçosa, Viçosa, MG, Brasil. Departamento de Medicina e Enfermagem. Graduando em Medicina.

https://orcid.org/0000-0002-8031-1196 - kelvin.rocha@gmail.com

Contribuição: Escrita- rascunho original.

\section{5 - Felipe Oliveira Martins}

Universidade Federal de Viçosa, Viçosa, MG, Brasil. Departamento de Medicina e Enfermagem. Graduando em Medicina.

https://orcid.org/0000-0002-4580-7313 - fepaomartins@gmail.com

Contribuição: Escrita- rascunho original.

\section{6 - Brunnella Alcantara Chagas de Freitas}

Universidade Federal de Viçosa, Viçosa, MG, Brasil. Departamento de Medicina e Enfermagem. Doutora em Ciência da Nutrição.

https://orcid.org/0000-0002-7863-0681 - brunnella.freitas@ufv.br

Contribuição: Conceptualização, curadoria de dados, análise formal, investigação, metodologia, escrita - rascunho original, escrita - revisão e edição. 